\title{
ARTICLES
}

\section{Mobile Individualism: The Subjectivity of EU Citizenship}

\author{
Aristel Skrbic
}

\section{Introduction}

Within the manifold debates on EU law, several scholars have recently turned to examining the connection between law and subjectivity in the European context. ${ }^{1}$ This new debate focuses on the construction of the legal person in Union law, specifically within the purview of EU citizenship and the case law of the Court of Justice of the European Union (CJEU). What is at stake here is whether EU law promotes a certain type of person over another, whether it prefers a certain form of life. If so, what is that form of life which is granted exemplary status by EU law? Embarking on this line of questioning breaks with the more customary method of analysing EU citizenship, which discusses different constellations of rights and obligations, framing these under the umbrella terms of liberal, republican, or market citizenship and then subjecting these legal bundles of rights and duties to normative examination. ${ }^{2}$ The debate this article joins, on the other hand, has taken a more anthropological turn by investigating the subjectification exercised by EU law over its subjects. ${ }^{3}$ Formulating this idea in the ancient vocabulary, we could say that each type of 'regime' corresponds to a certain type

1 Alexander Somek, Individualism: An Essay on the Authority of the European Union (Oxford: Oxford University Press, 2008); Joseph H.H. Weiler, 'Van Gend en Loos: The individual as Subject and Object and the Dilemma of European Legitimacy,' I•CON 12, no. 1 (2014): 94-103; Loïc Azoulai, 'The European Individual as Part of Collective Entities (Market, Family, Society)', in Constructing the Person in EU Law: Rights, Roles, Identities, eds. Loïc Azoulai, Ségolène Barbou des Places and Etienne Pataut (Oxford: Hart Publishing, 2016), 203-24.

2 Jürgen Habermas, 'Democracy in Europe: Why the Development of the EU into a Transnational Democracy Is Necessary and How It Is Possible', European Law Journal 21, no. 4 (2015): 546-57; Andreas Follesdal and Simon Hix, 'Why There Is a Democratic Deficit in the EU: A Response to Majone and Moravcsik,' Journal of Common Market Studies 44, no. 3 (2006): 533-62; Richard Bellamy, “'An Ever Closer Union Among the Peoples of Europe”: Republican Intergovernmentalism and Demoicratic Representation within the EU', Journal of European Integration 35, no. 5 (2013): 499-516.; Niamh Nic Shuibhne, 'The Resilience of EU Market Citizenship,' Common Market Law Review 47, no. 6 (2010): 1597-1628; Dimitry Kochenov, 'EU Citizenship without Duties,' European Law Journal 20 no. 4 (2014): 482-98.

3 Marco Dani, 'The Subjectification of the Citizen in European Public Law', in Constructing the Person in EU Law, eds. Azoulai, Barbou des Places and Pataut, 55-88; Somek, Individualism. See also Nikolas Rose, Inventing Our Selves - Psychology, Power and Personhood (Cambridge: Cambridge University Press, 1996). 
of human 'soul'. ${ }^{4}$ Following this approach, the present article is guided by the following question: what kind of a person does EU citizenship encourage one to be? The answer I would like to propose is simple if troubling: a citizen who is an individualist. More specifically, I will suggest that the concept of mobile individualism offers a promising theoretical framework for understanding the unique nature of EU citizenship.

The article consists of three parts. In part one I will lay out at some length the concept of individualism as used by Alexander Somek in respect to EU citizenship, since his analysis forms the basis of my paper. I will also contrast Somek's use of Tocquevillian individualism with Loïc Azoulai's notion of 'pure individualism'. In the second part I will closely analyse a small number of CJEU's judgements from the family case law, focusing on the role of the purely internal rule. My argument here will be that the freedom of movement sits at the core of EU citizenship. In the final part of the paper I will outline the notion of mobile individualism and propose it as an updated version of Tocquevillian individualism. My suggestion is that mobile individualism better captures the transnational nature of EU citizenship since it focuses on movement as its central object of analysis.

\section{Individualism and EU citizenship}

The starting point of my paper is Alexander Somek's claim that the concept of individualism represents the type of subjectivity suited to the nature of EU law. In other words, an individualist person would be a model EU citizen. ${ }^{5}$ It is beyond the scope of this paper to conduct a thorough analysis of EU law and determine whether the concept of individualism is indeed best suited for understanding the subjectivity of an EU citizen. Instead, I will argue that if Somek is right in using the notion of individualism in the context of the EU, then it needs to be updated so as to capture the unique characteristics of EU citizenship.

Somek's analysis mainly focuses on CJEU's internal market jurisprudence, closely analysing the case law on risk regulation in tobacco advertising and consumption. ${ }^{6}$ His account of individualism is based on Tocqueville's Democracy in America in which the concept of individualism is introduced for the first time. ${ }^{7}$ Somek writes that at its core individualism disposes citizens to retreat to the private sphere and to seek pleasure and enjoyment in the company of personal friends and members of the immediate family'. ${ }^{8}$ Historically, this is supposed to have happened with the advent of democracy, the rise of social power, and the widen-

4 See Leo Strauss, The City and Man (Chicago: Chicago University Press, 1978). This idea was of course first formulated by Plato in the Republic. In relation to the EU, see Somek, Individualism, 1.

5 Somek, Individualism, 200-26.

6 Somek, Individualism, ch. 3-7. Somek also briefly discusses EU citizenship itself, from the perspective of solidarity. See chapter 10.

7 Alexander de Tocqueville, Democracy in America, trans. H.C. Mansfield and D. Winthrop (Chicago: University of America Press, 1989).

8 Somek, Individualism, 189. 
ing but loosening of social bonds. ${ }^{9}$ In Tocqueville's own words, individualism entails an abandoning of 'society at large to itself. ${ }^{10}$ This retreat is not a moral flaw according to Tocqueville, but an error of judgement or 'defect of the mind,' as he calls it, which makes an individualist misperceive the nature of the social bond. Thus, Tocquevillian individualism should not be confused with selfishness, nor with some more recent theories of moral individualism which claim that only individual (and never collective) goods matter. ${ }^{11}$ Tocqueville's individualist recognises the importance of some collective goods, but these are invariably narrow, the good of the family or a close circle of friends, and never societal or political goods. With the pursuit of the common good out of the picture, depoliticisation follows. ${ }^{12}$ Can such a depoliticised person still be called a citizen in any meaningful sense? As Somek argues in a more recent article, being an individualist citizen $^{13}$ at its core involves a degree of 'civic interpassivity', which allows such citizens to 'defer to the authority of an imaginary other who is supposed to understand what is going on and in whom they may comfortably trust'. ${ }^{14}$ Such deference is of course only successful if enough of us practice it. Insofar as the political arena is one in which citizens can resolve their disagreements and choose a common course of action this can be achieved, inter alia, by common civic activity or by common civic interpassivity. Individualist citizens in effect contract-out their decision making to the other. In our case these 'contractors' are national and European technocrats, national executive branches acting as transnational legislators and, centrally for our investigation, the judges of the CJEU who perhaps play the most important role in the construction of EU citizenship. Depoliticisation or civic interpassivity, then, sit at the core of this conception of individualism.

But why use the concept of individualism to capture this state of affairs? There are a number of authors who share Somek's analysis of a European citizen as a depoliticised individual without resorting to the notion of individualism. Pierre Manent, for example, speaks of the separation of the 'citizen' and the 'individual'. ${ }^{15}$ As a European citizen, one is still an individual, with rights and private liberties, but one is no longer a citizen in the republican sense; one is no longer called upon to actively shape the common destiny of a polity. John Pocock argues in a similar vein and further claims that 'political relations are replaced by market relations' in the EU and calls this state of affairs the 'empire of the market'. ${ }^{16}$ In

9 Somek, Individualism, 189.

10 Tocqueville, Democracy in America, 482.

11 See Joseph Raz, The Morality of Freedom (Oxford: Clarendon Press, 1986).

12 See also John G.A. Pocock, The Discovery of Islands (Cambridge: Cambridge University Press, 2005); Pierre Manent, A World Beyond Politics? A Defense of the Nation-State (Princeton: Princeton University Press, 2006).

13 Here he uses the term 'cosmopolitan individual' but ascribes to her largely identical features to those he previously ascribed to the individualist.

14 Alexander Somek, 'Europe: Political, Not Cosmopolitan', European Law Journal 20, no. 2 (2014): 150.

15 Manent, World Beyond Politics?, 61.

16 Pocock, Discovery of Islands, 282. 
the EU citizenship literature this lack of the political dimension is probably best captured by the notion of 'market citizenship'. ${ }^{17}$ What stays implicit in all of these accounts, however, is the type of person that would make a model EU citizen. It is by referring to Tocqueville's concept of individualism that Somek can say something about the subjectivity of a depoliticised person. As mentioned above, for Tocqueville individualism is not about selfishness but about a cognitive 'mistake' about the nature of the social bond. One becomes an individualist by underestimating the degree to which one is dependent on others, specifically by believing that a good life can be achieved in private and without civic engagement. ${ }^{18}$ The 'misunderstanding of the social bond'19 is the individual subjectivity corresponding to the general state of depoliticisation. Within this Tocquevillian framework, the ascendancy of market relations comes as a consequence of depoliticisation. When there is no political commitment to the common good which can mediate relationships between citizens, market transactions take its place. As the political recedes, social power grows. ${ }^{20}$

I will follow the Tocquevillian notion of individualism, as employed by Somek in the EU context, when I propose an updated version of the concept in the last part of the paper. But it is first necessary to distinguish this use of individualism from the way Azoulai refers to the concept. Azoulai argues that the general characterisation of EU citizenship as based on 'individual emancipation and self-determination' ${ }^{21}$ is incomplete. If this were the case, then EU citizenship would affirm 'pure individualism' which Azoulai describes as 'the view that individuals are entirely inward-looking beings for whom only individual goods, and no collective goods, matter' ${ }^{22}$ Rather than affirming pure individualism, EU law 'allows individuals to be part of collective entities'. ${ }^{23}$ Through analysing a range of internal market and family law cases, Azoulai argues that EU citizenship at its core allows individuals to free themselves from the home member state situation and 'reconstruct' themselves in one or multiple other member states. ${ }^{24}$ In other words, there is a relational aspect to EU citizenship which aims to empower individuals to establish and maintain various social ties, from family to education, employment to residence. Azoulai's use of the concept of individualism needs to be distinguished from the Tocquevillian notion which I employ. Pure individualism, as Azoulai describes it, corresponds to some contemporary versions of the concept which see all collective goods as instrumental, ${ }^{25}$ or all value as agent-relative. ${ }^{26}$ Simply put, only individuals are of intrinsic value and all other things or collective entities are of value insofar as they matter to individuals. This is a rather strong conception

17 Nic Shuibhne, 'Resilience of EU Market Citizenship'.

18 Tocqueville, Democracy in America, 482.

19 Somek, Individualism, 189.

20 Tocqueville, Democracy in America, 659.

21 Azoulai, 'European Individual', 204.

22 Azoulai, 'European Individual', 204.

23 Azoulai, 'European Individual', 204.

24 Azoulai, 'European Individual', 205.

25 See Raz, Morality of Freedom.

26 Eric Mack, 'In Defense of Individualism', Ethical Theory and Moral Practice 2 (1999): 87-115. 
of individualism and on this definition, I would agree with Azoulai that EU citizenship is not individualist. In fact, it is hard to conceive of a legal structure of citizenship which would affirm such 'pure individualism'. But Azoulai's own analysis of EU citizenship still falls squarely within the Tocquevillian sense of individualism. For Tocqueville, one does not have to be a 'totally inward-looking being' to qualify as an individualist. It is enough that 'only those nearest to us are of any concern' ${ }^{27}$ What is crucial is the depoliticization of the individual which is based on a belief that the good life is attainable without political engagement. On Azoulai's account this is precisely what EU law encourages citizens to do. On the one hand 'EU law is keen to release individuals from their original political allegiances,' while on the other it empowers them to 'integrate into society instead of political community' ${ }^{28}$ of another member state. In this sense EU citizenship is an inversion of national citizenship, giving priority to the social over the political.

The classical analysis of individualism developed by Tocqueville and used by Somek is able to account for the general trend of depoliticisation which has been underway for the past century or so in Western democracies and which is surely exemplified in the EU today. But I will try to show that EU citizens are not simply given private rights and short-changed on political rights. Because of the nature of EU's competences and CJEU's jurisprudence even private rights such as the right to family life are determined with reference to the freedom of movement. It thus takes a very peculiar act - the crossing of a border - to activate the rights belonging to the status of EU citizenship. In the next section I will analyse three CJEU cases on family law with the aim of explicating the so-called 'purely internal rule' which I believe is key to understanding the particular nature of EU citizenship. To make sense of this new form of citizenship I will suggest we should employ the notion of mobile individualism, an updated version of Tocquevillian individualism to capture more precisely the subjectivity of a model EU citizen.

\section{EU citizenship and the purely internal rule}

EU citizenship was first introduced in the Treaty of Maastricht, but it was arguably the CJEU which transformed 'weakly conceived legal institutions into strong concepts of rights' ${ }^{29}$ As it did in the early days of the EEC with breakthrough rulings such as Van Gend ${ }^{30}$ and Costa, ${ }^{31}$ the Court adopted a proactive stance in the effort to 'construct' a new status for European nationals. ${ }^{32}$ The manner in which it did so, however, is somewhat ambivalent. Looking at the case law, at least two approaches can be detected. The first is based on Article 20 of the Treaty on the

27 Tocqueville, Democracy in America, 589.

28 Azoulai, 'European Individual', 212.

29 Stefan Kadelbach, 'Union Citizenship', in Principles of European Constitutional Law, eds. Armin Von Bogdandy and Jürgen Bast (Oxford: Hart Publishing, 2006), 453.

30 Case C-26/62, Van Gend en Loos v. Administratie der Belastingen, ECLI:EU:C:1963:1.

31 Case C-6/64, Costa v. E.N.E.L., ECLI:EU:C:1964:66.

32 Dora Kostakopoulou, 'Ideas, Norms and European Citizenship: Explaining Institutional Change', Modern Law Review 68, no. 2 (2005): 233. 
Functioning of the European Union (TFEU) which establishes the status of EU citizenship and proclaims that every national of a member state shall also be a Union citizen. ${ }^{33}$ Within the context of Article 20 TFEU we can understand the proclamation that EU citizenship is 'destined to be the fundamental status of nationals of the Member States', ${ }^{34}$ as well as certain borderline cases such as Ruis Zambrano $^{35}$ and Rottmann, ${ }^{36}$ the first of which will be discussed below. The second approach of the Court, however, is more in continuation with its previous case law on economic movement and is predominant. ${ }^{37}$ The majority of citizenship cases are decided on the basis of Article 21 TFEU $^{38}$ and Directive 2004/38, ${ }^{39}$ both of which deal with the free movement provisions. By relying on free movement as the core right underpinning the development of EU citizenship, the Court employs principles and methods developed in relation to the internal market. Concepts such as discrimination, obstacles, and unjustified or disproportionate restrictions thus find their way into citizenship case law. ${ }^{40}$

Such an approach makes sense from the perspective of logical and narrative coherence since it diminishes the gap between market citizenship and EU citizenship. The rights which were bestowed upon migrant workers before the introduction of EU citizenship have been progressively extended to all those who have moved from their home member state and into a host member state, although there is still some differentiation of rights tied to economic status. ${ }^{41} \mathrm{I}$ call this approach 'functional' since it requires that the EU citizen performs a certain function before her rights are activated. ${ }^{42}$ In the early days of market citizenship this function was primarily economic while in the more recent EU citizenship case law it is movement which activates citizenship rights. The two approaches to EU citizenship are clearly in tension with one another, since the free movement approach based on Article 21 leaves out the sedentary EU citizens and is in consequence hardly compatible with the 'fundamental status' approach based on Artinor Spaventa (London: Hart Publishing, 2012), 16.

41 An economically non-active EU citizen needs to prove other ties to the host member state and does not qualify for certain benefits in the same way as an economically active citizen. See Directive 2004/38 (21).

42 This functional treatment of the individual in EU law can be traced all the way back to Van Gend en Loos. See Weiler, 'Van Gend en Loos'. 
cle 20. In order to spell out this tension I turn to explicating the purely internal rule and reverse discrimination by looking closely at three cases.

\section{The purely internal rule}

The EU's powers are based on the principle of conferral, as laid out in Article 5 of the Treaty on European Union (TEU). ${ }^{43}$ This means that member states have to expressly attribute a specific power to the EU in order for the latter to have regulatory jurisdiction. In respect to EU citizenship this means that the EU only has powers 'within the scope of application of the Treaties', ${ }^{44}$ i.e. there has to be a transnational dimension to the case in order for EU law to apply. The purely internal rule and reverse discriminations result from this structural feature of EU law.

The Court articulated the purely internal rule in 1979, first in Knoors ${ }^{45}$ and shortly after in Saunders. ${ }^{46}$ The Knoors case involves a Dutch national who is seeking rights and protections emanating from the EU directive regulating selfemployment against his own home state. ${ }^{47}$ The Court states that Treaty provisions on establishment and services do not apply to situations which lack a transnational element, so on first sight a Dutch national could not rely on EU regulations against The Netherlands. However, because the applicant has in the past resided and exercised his profession in another member state, in addition to having been trained there, the Court found that Knoors falls outside the purely internal rule and thus within the scope of application of the Treaty. ${ }^{48}$ By having crossed a border and engaged in economic activity, Mr. Knoors has performed the rights-activating function in the eyes of EU law and thereby acquired a set of European rights which he can use against his own member state. In Saunders, conversely, no transnational element could be found and so Union law did not apply. ${ }^{49}$ Ms. Saunders, who was from Northern Ireland but worked in England, was convicted of stealing and ordered by the English courts that she stay confined in Northern Ireland for three years. She did not comply with the order and was later arrested, again. At that point she turned for protection to European law and claimed that the restriction placed on her movement by the English court went against the free movement provisions in the Treaty. As we can see, however, there is no transnational element to be found in this story and the applicant could not rely on any relevant factors that lay outside the United Kingdom. This led the Court to declare that applicants who find themselves in situations 'where

43 https://eur-lex.europa.eu/LexUriServ/LexUriServ.do?uri=CELEX:12008M005:EN:HTML.

44 Art. 18 TFEU, https://eur-lex.europa.eu/LexUriServ/LexUriServ.do?uri=CELEX:12008M005:EN: HTML.

45 Case C-115/78, Knoors v. Staatssecretaris van Economische Zaken, ECLI:EU:C:1979:31.

46 Case C-175/78, The Queen v. Saunders, ECLI:EU:C:1979:88.

47 Case C-115/78 Knoors (1979), para 2-6.

48 Case C-115/78 Knoors (1979), para 2-6.

49 Since this was a criminal case, an area in which EU law has very limited competence, it is unlikely Ms Saunders would receive the protection of EU law even if there was a transnational dimension to the case. 
there is no factor connecting them to any of the situations envisaged by EU law, 50 are excluded from the rights stemming from the EU free movement provisions. 'Situations envisaged by EU law' here stands for situations with a transnational and economic element.

The structure found in Knoors and Saunders largely persists to this day, despite the introduction of EU citizenship. The purely internal rule was grandfathered in from market citizenship into EU citizenship case law. To observe this dynamic at work in more recent case law we can turn to Metock. ${ }^{51}$ In this judgement the Court reversed its earlier decision from $A k i r c h^{52}$ and maintained that previous legal residence is not a requirement for the applicant to avail herself of the rights stemming from Directive 2004/38. In Metock, a right to residence was granted to a number of third country nationals who had married EU citizens after the latter had exercised their freedom of movement and moved to Ireland, even though these third country nationals were themselves unlawfully present on the Irish territory at the time. ${ }^{53}$ The Court reached the controversial decision of granting these spouses of EU citizens residency rights in view of 'the importance of ensuring the protection of the family life of nationals of the Member States in order to eliminate obstacles to the exercise of the fundamental freedoms that are guaranteed by the EC Treaty'. ${ }^{54}$ Once again, the EU citizens whose spouses are granted residence in Metock are fulfilling the function required for them to activate European rights. In Knoors, the functional requirement was that a subject be economically active in a transnational situation. In Metock, the economic requirement is dropped, but the transnational requirement is retained. At its core, this is the innovation of EU citizenship: economic activity in a host member state is no longer what activates EU citizenship rights, but rather the exercise of the freedom of movement for any purpose, economic or otherwise.

While the applicants in Metock fulfilled the functional requirements and could thus avail themselves of the family reunification rights, reverse discrimination is clearly lurking behind the facts of this case. A third country spouse of an Irish national who was previously illegally present in the territory would not qualify for family reunification. Tersely addressing this discrepancy in treatment, the Court simply states that those EU citizens who have not exercised their freedom of movement cannot rely on EU law in relation to residence and entry of their family members, since such purely internal situations fall outside of the scope of EU law. ${ }^{55}$ The fundamental distinction between those citizens who have crossed the border and those who have not has already been criticised as unjust, ${ }^{56}$ and litera-

Case C-178/78 Saunders (1979), para 11.

Case C-127/08, Metock, ECLI:EU:C:2008:449.

Case C-109/01, Akirch, ECLI:EU:C:2003:491.

Unlike in Akirch where prior lawful residence was a condition for the reunification clause to kick in.

Metock, para 56.

Metock, paras 77-78.

Eleanor Spaventa, 'Seeing the Wood Despite the Trees? On the Scope of Union Citizenship and its Constitutional Effects', Common Market Law Review 45, no. 1 (2008): 13. 
ture on reverse discrimination stemming from the purely internal rule abounds. ${ }^{57}$ But I would like to focus on the 'positive' development of EU citizenship itself, as exhibited in Metock and other cases related to family life, to investigate how the jurisprudence of the Court shapes the legal reality of being a Union citizen over time. Some commentators read the Court's reasoning in Metock as representing a 'recognition of the reality of family life in the context of mobility.'58 Others emphasise the progress towards equal treatment made from the wording of 'accompany or join' found in Directive 2004/38 which still shows the vestiges of the old economic approach where a male worker moved to the host member state and was 'accompanied' by his wife and children, to a situation where EU citizens are 'invited to develop new social and family relations' 59 in the host member state.

Structurally speaking, however, Metock brought a new situation of family life within the overall functional framework of EU citizenship. From this perspective, the expansion of citizenship rights within the domain of family reunification is not autonomous but rather attaches itself onto the transnational requirement of EU citizenship. This is revealed in the 'in order to' of the above statement of the Court. ${ }^{60}$ The wording of the judgement tells us that family life is not protected because it is some kind of a natural right, or because it is the settled will of the body politic resulting from the ongoing political opinion and will formation, but rather because it performs a necessary enabling function for the exercise of the freedoms granted by EU citizenship. Chief among these freedoms is, of course, the right to the freedom of movement. ${ }^{61}$ We can safely assume that the protection of family life is of great deontological importance to everyone sitting on the bench, but this does not alter the fact that in its ruling, the Court casts the right to family life in a functional role as a facilitator of the freedom of movement. This results in a strange outcome where the violation of the right to family life is no longer called an injustice, a violation of a fundamental human right, but rather a

57 Cf. Chiara Berneri, 'Protection of Families Composed by EU Citizens and Third-country Nationals: Some Suggestions to Tackle Reverse Discrimination', European Journal of Migration and Law 16, no. 2 (May 2014): 249-75; Alina Tryfonidou, Reverse discrimination in EC law (Alphen aan den Rijn: Kluwer Law International, 2009); Helen Oosterom-Staples, 'To What Extent Has Reverse Discrimination Been Reversed?', European Journal of Migration and Law 14, no. 2 (2012): 151-72.

58 Samantha Currie, 'Accelerated Justice or a Step Too Far? Residence Rights of Non-EU Family Members and the Court's Ruling in Metock', European Law Review 34, no. 2 (2009): 310-26.

59 Iliopoulou-Penot, 'Transnational Character of Union Citizenship', 27.

60 'the importance of ensuring the protection of the family life of nationals of the Member States in order to eliminate obstacles to the exercise of the fundamental freedoms that are guaranteed by the EC Treaty.' See n. 41.

61 Even in Art. 20 TFEU, freedom of movement is listed as the primary right stemming from EU citizenship, ahead of the right to vote in local and EU elections. https://eur-lex.europa.eu/legalcontent/EN/TXT/HTML/?uri=CELEX:12016E020\&from=EN. 
mere 'obstacle'. ${ }^{62}$ The resulting functional nature of EU citizenship is of course not merely due to the jurisprudence of the Court. While it was the decision of the Court to construct EU citizenship as a continuation of market citizenship, as well as to keep the purely internal rule, the foundation for this is found in the Treaties. Article 18 TFEU states that there shall be no discrimination between EU citizens on the grounds of nationality, but only in situations which fall within the scope of application of the Treaties. The purely internal rule, reverse discrimination, and the type of functionalist approach in which exercising the freedom of movement activates citizenship rights are all present in this Article in their germ form. Within the meaning of Article 18 TFEU, the Treaties only apply in transnational situations and, consequently, the vast majority of citizenship cases are decided by the Court on the basis of Article 21 TFEU, the primary legislation of the free movement provisions itself regulated by Directive 2004/38. The 'scope of the Treaties' pushes citizenship cases towards the free movement provisions and these can of course only interpret situations from the perspective of free movement, even if the situation is one chiefly concerning the right to family life. This line of CJEU's jurisprudence paints a picture of a transnational ${ }^{63}$ and functional ${ }^{64}$ notion of citizenship.

\section{The unfulfilled promise of Article 20 TFEU}

In an attempt to address the two-tier structure of EU citizenship which separates mobile from sedentary citizens, the Court has recently turned towards Article 20 TFEU which establishes the very status of EU citizenship, to confer rights on those applicants who have not availed themselves of the right to free movement. The most consequential case in this regard is Ruiz Zambrano. ${ }^{65}$ The Zambrano family was granted family reunification rights despite the fact that their situation was purely internal. This was the case, however, because their situation was very particular. Even though Mr. Zambrano is a Colombian national, his children were

62 We can see a somewhat analogous situation across the pond by looking at two 1964 rulings of the US Supreme Court, Heart of Atlanta Motel Inc v. United States and Katzenbach v McClung. In these two cases the logic that a violation of human rights can be tackled as an obstacle to free movement was employed in the context of the interstate commerce clause which empowered Congress to legislate and overrule the States. The Supreme Court recognised in its judgements that the exclusionary politics practised against black travellers in the two cases constituted a 'moral and social wrong', but it empowered the Congress to do something about it via the commerce clause not on any human rights grounds but rather due to the 'overwhelming evidence of the disruptive effect that racial discrimination has had on commercial intercourse'. This manoeuvre opened the door to federal regulation in ethically and politically deeply contested areas, all on the back of a 'modest' commerce regulation. To temper the excessive use of this mechanism by Congress, the Supreme Court limited its field of application in the 1990s by ruling that only those human rights abuses which substantially hinder interstate commerce can be regulate through the use of the commerce clause.

63 Síofra O'Leary, 'The Past, Present and Future of the Purely Internal Rule in EU Law', in Empowerment and Disempowerment of the European Citizen, eds. Michael Dougan, Niamh Nic Shuibhne and Eleanor Spaventa (London: Hart Publishing, 2012), 38-71; Azoulai, 'European Individual as Part of Collective Entities'; Iliopoulou-Penot, 'Transnational Character of Union Citizenship.'

65 Case C-34/09, Ruiz Zambrano, ECLI:EU:C:2011:124. 
given Belgian citizenship upon birth in Belgium because they would have otherwise been rendered stateless due to Colombian laws at the time. It of course follows that if Mr. Zambrano would be made to leave EU territory, his children, as minors, would have to leave as well. The question facing the Court was whether Mr. Zambrano could be granted residency rights in Belgium on the back of his children, EU citizens who had never exercised their right to the freedom of movement. By consulting Article 21 TFEU and Directive 2004/38 the answer would be negative, but the Court answered in the affirmative and grounded its judgement in Article 20 TFEU. If Mr. Zambrano was forced to leave EU territory, his children would be deprived of 'the genuine enjoyment of the substance of the rights attaching to the status of European Union citizen', 66 a violation so severe that the Article protecting the very status of EU citizenship could be called upon. ${ }^{67}$ This case opened the possibility of gradually addressing some of the issues I have raised in the paragraphs above, from the purely internal rule and reverse discrimination to the functional conception of citizenship which is activated upon crossing a border. In its Zambrano ruling, though, the Court did not answer the pertinent question raised by the referring judge. The question was whether there is a right to residence to be found in Articles 18, 20, and 21 TFEU, read separately or in conjunction, even in a situation where no movement has taken place. Despite AG Sharpston's analysis of this question, ${ }^{68}$ the Court shied away from this opportunity to recast the structure of EU citizenship by relying more heavily on Article 20 TFEU.

We did not, however, have to wait long to find out the Court's position on the question posed in Zambrano. In the McCarthy ${ }^{69}$ ruling the Court backtracked greatly on its innovative approach, signalling that Zambrano was indeed a unique case. Ms. McCarthy has both Irish and UK citizenship, but she was born and has always lived in the United Kingdom. She married a Jamaican national who did not have the right to residence under British Immigration regulations, at which point Ms. McCarthy turned to Directive 2004/38, believing that in conjunction with her Irish nationality and her residence in the UK it would allow her to qualify for family reunification under EU rules. Following from the Metock ruling, Ms. McCarthy's spouse had some hope of being granted residence, but the Court ruled negatively to her appeal. Since she had not exercised her right to the freedom of movement, despite being a dual national, in her case the Directive did not apply. The Court did not have to go any further than this in its ruling, but in a surprising move the judges provided an extended interpretation of primary law and thus answered the question left open from Zambrano. The Court stated that Article 21

68 He answers the first question positively, stating that within the meaning of Art. 21 TFEU, the right to residence is independent of the right of free movement (para 100-101 of the Opinion). The second question is also answered in the affirmative, where according to AG Sharpston 'Article 18 TFEU should be interpreted as prohibiting reverse discrimination (...)' (para 144 of the Opinion).

69 Case C-434/09, McCarthy, ECLI:EU:C:2011:277. 
TFEU does not apply to sedentary EU citizens, regardless of whether they possess dual nationality. ${ }^{70}$ The Court also recognised that Zambrano presented an exception to this rule, based on the particular facts of the case by which the genuine enjoyment of the status of EU citizenship itself was at stake. The situations of Ms. McCarthy and the Zambrano children were different in one crucial respect: denying their father residency rights would mean these minor EU citizens would have to leave EU territory, whereas denying this right to Ms. McCarthy's spouse would leave her enjoyment of EU citizenship rights intact. By opting for a narrow reading of the implications of Zambrano in the $M c$ Carthy case, ${ }^{71}$ the Court chose not to take the construction of EU citizenship towards developing a status which confers rights without posing any functional requirements. Instead, the Court signalled that a self-standing reliance on Article 20 TFEU is only possible in exceptional cases with peculiar factual circumstances such as those in Zambrano. $^{72}$

This brings to a close my argument that even the recent case law on EU citizenship, at least in the area dealing with the right to family life, is still pervaded by the logic which makes the activation of citizenship rights dependent on performing a certain function. What follows from this is that the apparent expansion of rights which we can trace in the case law does not in fact amount to an expansion of rights, but rather represents an ever-wider domain which can be functionally linked to the freedom of movement. Because the Court does not have the authority to increase the ratio materiae of EU law but at the same time has chosen to proactively construct the rights stemming from EU citizenship, such a course was almost inevitable. The Court's venturing beyond the free movement approach grounded in Article 21 and drawing on Article 20 in Zambrano has proved to be exceptional and probably will not change the basic structure of EU citizenship. All of this brings us back to the question of individualism and the subjectivity of a model EU citizen. In the last section of the article I will seek to update Tocqueville's notion of individualism to capture the unique movement-based nature of EU citizenship.

\section{The subjectivity of EU citizenship}

It is clear that EU citizenship focuses mainly on private or liberal rights and less so on political rights. The current discussion on EU citizenship thus often suggests that it is at its core a type of liberal citizenship, where private rights are guaranteed even if without the corresponding notion of popular sovereignty. ${ }^{73}$ But my analysis of the case law above argues that even liberal rights are in the

70 McCarthy, para 50.

71 This narrower reading was later confirmed in Case C-256/11, Dereci, ECLI:EU:C:2011:734.

72 See also the more recent Case C-133/15, Chavez-Vilchez and Others, ECLI:EU:C:2017:354. To an extent, Case C-135/08, Rottmann, ECLI:EU:C:2010:104, and Case C-148/02, Garcia Avello, ECLI:EU:C:2003:539 are exceptions in a similar vein.

73 Floris de Witte, 'Emancipation Through Law?', in Constructing the Person in EU Law, eds. Azoulai, Barbou des Places and Pataut, 15-34. 
jurisprudence of the Court placed in a subordinate position in relation to the right to freedom of movement. Even though the language of rights is present in the jurisprudence of the Court, it is never self-standing, but rather depends on the prior exercise of free movement in order to be activated. ${ }^{74}$ The structure of EU citizenship which thus unfolds is one where political rights are underdeveloped and even liberal rights are not self-standing, but rather functionally dependent on the exercise of the freedom of movement. So, what is the type of subjectivity corresponding to this kind of citizenship?

\section{Mobile individualism}

I suggest EU citizenship would be best understood through the lens of mobile individualism. This revised notion of individualism grants depoliticisation its due but focuses on movement as its central category for analysis. As we have seen, Article 21 TFEU and Directive 2004/38 are the main regulatory sources on the basis of which EU citizenship cases are decided. Their primary aim is usually described as providing the rights and protections that facilitate the leaving of one's home member state and help one integrate into the host member state. ${ }^{75}$ Azoulai goes further and suggests that EU citizenship at its core allows one to 'circulate among territories as well as various social and institutional spheres prevalent in the Member States'. ${ }^{76}$ Thus, we have the more common situation in which a citizen of one member state simply moves to another and makes her new home there, alongside the more intense version of continuous movement or 'circulation.' Such a citizen is educated in one country, works in another, sends money to family in yet another, and may one day return to her home member state before once again leaving to seek her fortune elsewhere. In either reading, mobility plays a crucial role in understanding the subjectivity of the model EU citizen.

To account for movement as a central component of EU citizenship, my notion of mobile individualism updates Somek's use of Tocquevillian individualism in two respects. (1) Depoliticisation is one of the central characteristics of individualism. In Tocqueville's story, depoliticisation is a result of withdrawing from the political community into the private confines of one's social circle. ${ }^{77}$ In mobile individualism, on the other hand, one does not withdraw but rather leaves the home political community. ${ }^{78}$ This leads to the second and more important distinction. (2) In Tocquevillian individualism the circle of family and friends stays intact, the social fabric is preserved. In mobile individualism, on the other hand, one typically leaves family and friends behind. Even when whole nuclear families exercise their

74 With the above-noted exceptions such as Chavez-Vilchez, Zambrano, Garcia Avello, and Rottmann.

75 Iliopoulou-Penot, 'Transnational Character of Union Citizenship', 17.

76 Azoulai, 'European Individual as Part of Collective Entities', 204.

77 Tocqueville, Democracy in America, 482.

78 Despite the rights to vote in local and European elections in one's host member state, civic participation remains patchy at best due to a mixture of linguistic, cultural, and other reasons; the first among these being the fact that national elections are still the most salient manifestation of the political life of a community. Being excluded from national elections makes EU citizens second class citizens from the republican perspective of civic participation. See Rainer Bauböck, ed., Debating European Citizenship (Cham: Springer Open, 2019). 
right to the freedom of movement together, this nonetheless changes the nature of the family and its relation to the wider social sphere. Individuals and families 'reconstruct themselves'79 in the new setting of the host member state. Tocquevillian individualism and mobile individualism as concepts thus make sense of distinct splits within society. The former characterises depoliticised individuals and stands in contradistinction to a more civic-minded type of subjectivity, while the latter captures the mobile-cosmopolitan part of the population as distinct from the sedentary-provincial segment of the citizenry. ${ }^{80}$

I suggest that we need to recast the concept of individualism along the mobilesedentary axis in order to make sense of EU citizenship insofar as the exercise of the freedom of movement is the activating factor of rights stemming from EU law. While Somek touches upon the issue of mobility in his discussion of individualism and EU citizenship, ${ }^{81}$ he does not work out the consequences this new dimension has for the concept of individualism itself. As I have argued, Tocquevillian individualism needs updating to capture the transnational character of EU citizenship. First, the cause of depoliticisation needs to be relocated from withdrawing to leaving. And even more importantly, while in Tocqueville's analysis the circle of family and friends stays intact in the case of EU citizenship both of these are 'reconstructed'. The precise contours of this updated individualist subjectivity need to be worked out to give a more complete account of EU citizenship than the one proposed by Somek.

\section{Conclusion}

If my analysis of the nature of the legal framework of EU citizenship has some merit, then I would propose that we need to further investigate the newly emerging form of life facilitated by this novel type of citizenship. Following some of the scholars who have recently investigated this issue, and in particular Somek's turn to Tocquevillean individualism, I have attempted to briefly sketch out this paradigm for understanding the form of life which is exemplary of EU citizenship. My main contribution was to further specify the nature of individualism found in the EU by coining the notion of mobile individualism, at the core of which stands the willingness of the exemplary EU citizen to uproot herself and reconstruct her life in a host member state or even lead a nomadic life. If further research shows that the concept of mobile individualism does indeed hold some explanatory power of the form of life adopted by the model EU citizen, then we can raise the normative question: is mobile individualism a new name for the good life or rather a deformation of the values of civic virtue and community which we still hold dear?

80 Nora Siklodi, 'Active Citizenship through Mobility? Students' Perceptions of Identity, Rights and Participation in the EU', Citizenship Studies 19, nos. 6-7 (2015): 1-16; Iliopoulou-Penot, 'Transnational Character of Union Citizenship', 34. 